\title{
Liquid Organic Fertilizer Production From Kersen Leaves (Muntingia Calabura L.) And Eggshells With Addition Of Spoiled Rice Local Microorganism (Mol) Bioactivator
}

\author{
M.Yerizam ${ }^{1, *}$, Norfhairna Norfhairna ${ }^{2}$, Elina Margaretty ${ }^{1}$, Ibnu Hajar ${ }^{1}$, Meilianti \\ Meilianti ${ }^{1}$, Endang Supraptiah ${ }^{1}$, Idha Silviyati ${ }^{1}$, Jihan Salsabila ${ }^{1}$ \\ ${ }^{1}$ Politeknik Negeri Sriwijaya, Palembang, Indonesia \\ ${ }^{2}$ University Technology Malaysia, Malaysia \\ *Corresponding author. Email: yerizam@polsri.ac.id
}

\begin{abstract}
Organic fertilizer are fertilizer that work in increasing the biological, chemical and physical activities of the soil so that the soil becomes fertile and good for plant growth. Kersen leaves and eggshells are materials that can be used as liquid organic fertilizer because they contain various types of ions such as nitrogen $(\mathrm{N})$, phosphorus $(\mathrm{P})$, potassium $(\mathrm{K})$, magnesium $(\mathrm{Mg})$ and calcium $(\mathrm{Ca})$ ions. The production of liquid organic fertilizer is carried out using an anaerobic fermentation process. This study aims to obtain the optimum conditions for the volume of spoiled rice MOL bioactivator $(30,50$, and $70 \mathrm{ml})$ and fermentation time $(7,12$, and 18 days) to produce liquid organic fertilizer with the best quality. Parameters observed in the production of liquid organic fertilizer are nitrogen content, phosphorus content, potassium content (NPK), $\mathrm{pH}$ and color and scent. The results of the best quality liquid organic fertilizer were obtained in the $50 \mathrm{ml}$ addition of spoiled rice MOL. The optimum fermentation time for nitrogen and potassium content was obtained on the 18 th day, $0.01296 \% \mathrm{~N}$ and $0.2947 \% \mathrm{~K} 2 \mathrm{O}$, phosphorus content obtained on the 12 th day is $0.8928 \% \mathrm{P} 2 \mathrm{O} 5$, with the $\mathrm{pH}$ value of 6 , dark brown and odorless.
\end{abstract}

Keywords: Kersen leaves, egg shells, spoiled rice local microorganism, liquid organic fertilizer, fermentation.

\section{INTRODUCTION}

Indonesia is an agrarian country in which the agricultural zone performs an important position in the national economy, and lots of people live inside the agricultural sector. Fertilizers play an important role in increasing agricultural manufacturing and most farmers nonetheless rely upon inorganic fertilizers due to the fact inorganic fertilizers include several nutrients in big portions. Inorganic fertilizers used continuously can damage soil conditions, which could purpose the soil to harden quick, be less able to keep water, and quick grow to be acidic which in the end reduces plant productivity [1]. Liquid organic fertilizer is a solution due to the decomposition of organic substances derived from plant residues, animal, and human wastes which incorporate more than one nutrient detail. In preferred, liquid organic fertilizers do not harm the soil and vegetation even though used as frequently as feasible. further, liquid fertilizer can also be used as an activator to make compost [2].

Indonesia has numerous varieties of vegetation that can be used as alternative raw substances for the production of liquid natural fertilizers. one of the plants that may be used as an alternative raw material for fertilizer production is the Kersen plant (Muntingia Calabura L.), the leaves/twigs of the plant include numerous styles of ions such as nitrogen ions $(\mathrm{N})$, phosphorus $(\mathrm{P})$, potassium $(\mathrm{K})$, Magnesium $(\mathrm{Mg})$ and calcium $(\mathrm{Ca})$ so that this plant can be used as fertilizer [3]. in line with Iskak (2014) [4], cherry leaves and fruit can be processed or produced into liquid fertilizer by using extraction and fermentation methods, the quality of liquid fertilizer produced at the time of extraction and 
fermentation of 6 weeks with a weight/solvent ratio (three hundred $\mathrm{gr} / 500 \mathrm{ml}$ ) indicates the best concentration of ions is $2,04 \% \mathrm{~N}, 0,38 \% \mathrm{P}, 23,93 \% \mathrm{~K}$, and $12,08 \% \mathrm{Mg}$.

Besides kersen plants, the manufacture of liquid fertilizer can be combined with eggshell waste. Eggs are one of the foodstuffs that are widely consumed by the community because of how easy it is to process. The use of abundant materials, causes an abundance of eggshell waste to accumulate [5]. Eggshells can be used as fertilizer as a source of nutrients for plants because they have a large enough calcium content. The content of the eggshell consists of $97 \%$ calcium carbonate, the rest is phosphorus, magnesium, sodium, potassium, zinc, manganese, iron, and copper [6].

To get good quality fertilizer and faster fermentation time, the addition of organisms, namely microdegrading organic matter using bioactivators [7]. MOL (Local Microorganisms) spoiled rice is one of the bioactivators with ingredients that are very easy to have. Because in general, spoiled rice is no longer used and will be thrown away. The microorganism contained in MOL rice is Azotobacter with benefits as a decomposer [8]. The minimum technical standart for liquid organic fertilizer regulated in PERMENTAN No. 261/KPTS/SR.310/M/4/2019 can be seen in the following table :

Table 1. Liquid Organic Fertilizer Quality Standard

\begin{tabular}{ccc}
\hline Parameter & Unit & Standar \\
\hline C-organik & $\%$ & Min 10 \\
N-organik & $\%$ & Min 0,5 \\
pH & - & $4-9$ \\
Hara Makro & & \\
$-\mathrm{N}$ & $\%$ & $2-6$ \\
- & $\%$ & $2-6$ \\
$\mathrm{P}_{2} \mathrm{O}_{5}$ & & \\
- & & $2-6$ \\
$\mathrm{~K}_{2} \mathrm{O}$ & & \\
$\mathrm{Hara}$ Mikro & & \\
- Fe total & $\mathrm{ppm}$ & $90-900$ \\
- Mn total & $\mathrm{ppm}$ & $25-500$ \\
- Cu total & $\mathrm{ppm}$ & $25-500$ \\
- Zn total & $\mathrm{ppm}$ & $25-500$ \\
- B total & ppm & $12-250$ \\
- Mo total & ppm & $2-10$ \\
\hline
\end{tabular}

This study aims to achieve the effect of variations in the volume of the MOL bio activator of stale rice and fermentation time on the NPK content material of liquid organic fertilizer, the optimum conditions for producing liquid organic fertilizer with parameters which include NPK content, $\mathrm{pH}$, colour, and aroma, and to obtain the quality of liquid organic fertilizer that is predicted to be suitable. with quality standards primarily based on PERMENTAN No. 261/KPTS/SR.310/M/4/2019.

\section{METHOD}

\subsection{Material}

The materials used in this study were spoiled rice, kersen leaves, egg shells, water, sugar and molasses.

\subsection{Procedure}

Research procedure this research is consist of two stages, namely 1) Making Local Microorganisms (MOL) Spoiled Rice, 2) Making Liquid Organic Fertilizer Local. Microorganisms (MOL) Spoiled Rice is made by mushrooming $100 \mathrm{~g}$ of spoiled rice for 5 days. Spoiled rice that has been moldy is mixed with 50 grams of sugar and 1 litre of water until evenly distributed. The mixture is put into a bottle with a hole in the lid and then a clear tube is inserted for the process of removing gas from the fermenter. Then the mixture is fermented for 7 days The next stage is the manufacture of liquid organic fertilizer. The raw materials used are kersen leaves and egg shells each 300 grams for each fermenter. The raw materials are cleaned and mashed using a blender to a small size. Then prepared MOL solution of spoiled rice with volume variations of 30 , 50 , and $70 \mathrm{ml}$. refined material is mixed with a MOL solution of spoiled rice, $50 \mathrm{ml}$ of molasses and $1500 \mathrm{ml}$ of water until evenly distributed. After that, the mixture is put into a conductor which is used as a fermenter. The lid of the fermenter is perforated with scissors and a clear hose is inserted for the gas removal process. The fermentation process takes place with variations in time for 7, 12, and 18 days. After the fermentation process is complete, the liquid organic fertilizer is filtered through a sieve to separate the liquid from the dregs. The samples obtained were analyzed for $\mathrm{pH}$, color, and aroma, and content of $\mathrm{N}, \mathrm{P}$, and $\mathrm{K}$. The methods used were UV-Vis spectrophotometer (for $\mathrm{N}$ and $\mathrm{P}$ ) and AAS spectrophotometer (for K).

\section{RESULT AND DISCUSSION}

\subsection{Characteristics of Liquid Organic Fertilizer}

Based on the observations that have been made on the liquid organic fertilizer of kersen leaves and egg shells, the liquid fertilizer produced after the fermentation process causes white spots on the surface of the liquid, and the color and aroma of the liquid organic fertilizer can be seen in Table 2 . acid is close to neutral, which is at a $\mathrm{pH}$ of 5-6. According to Prahesti and Dwipayanti (2011)[9], the acidic $\mathrm{pH}$ close to neutral is formed by the activity of bacteria that convert organic acids into simpler compounds such as methane, ammonia, and carbon dioxide $(\mathrm{CO} 2)$. The $\mathrm{pH}$ value will affect microbial activity during the composting 
process, the optimum $\mathrm{pH}$ for the decomposition of organic matter ranges from 6.5 to 7.5 [10]. Damayanti, et al. (2018) [11] reported that microbes from liquid organic fertilizers with the highest and best growth were at $\mathrm{pH}$ 6.5. In this study, the $\mathrm{pH}$ value of the liquid organic fertilizer obtained has met the requirements Minimum Technical PERMENTAN No. 261/KPTS/SR.310/M/4/2019, namely 4-9.

Table 2. Characteristic Liquid Organic Fertilizer

\begin{tabular}{ccccc}
\hline $\begin{array}{c}\text { Volume MOL } \\
(\mathrm{ml})\end{array}$ & $\begin{array}{c}\text { Fermentation Time } \\
\text { (Day) }\end{array}$ & $\mathrm{pH}$ & Colour & Aroma \\
\hline \multirow{3}{*}{30} & 7 & 5 & Dark Chocolate & Smell not pungent \\
& 12 & 5 & Dark Chocolate & Smell not pungent \\
& 18 & 5 & Dark Chocolate & Strong Smells \\
\hline \multirow{2}{*}{50} & 7 & 6 & Dark Brown & Strong smell \\
& 12 & 6 & Dark Brown & Smell not pungent \\
70 & 18 & 6 & Dark Brown & Smell not pungent \\
\hline \multirow{2}{*}{ PERMENTAN No } & 18 & 6 & Yellowish brown & Strong Smells \\
261/KPTS/SR.310/M/4/2019 & 6 & Yellowish brown & Smell not pungent \\
\hline
\end{tabular}

\subsection{Nitrogen, Phosphorus and Potassium Content of Liquid Organic Fertilizer}

Before the fermentation process is completed inside the production of liquid fertilizers, first an evaluation of the nutrient content material of nitrogen, phosphorus, and potassium contained in raw materials. the following are the results of the evaluation of the nutrient content material of kersen leaves and eggshells.

Table 3. Results of Analysis of Nutrient Content in Raw Materials

\begin{tabular}{|l|c|c|c|}
\hline Materials & $\underline{\mathrm{N}(\%)}$ & $\underline{\mathrm{P}_{2} \mathrm{O}_{5}(\%)}$ & $\underline{\mathrm{K}_{2} \mathrm{O}(\%)}$ \\
\hline Kersen Leaves & 0,00560 & 0,1676 & 0,0414 \\
\hline Egg shells & $\underline{0,00325}$ & $\underline{0,0537}$ & $\underline{0,0213}$ \\
\hline
\end{tabular}

\subsubsection{Nitrogen Content}

Nitrogen is the primary nutrient for plant growth because nitrogen is needed for the formation or growth of vegetative elements of plants including plant peak and quantity of leaves

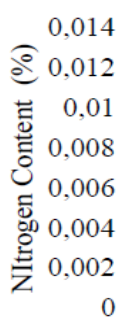

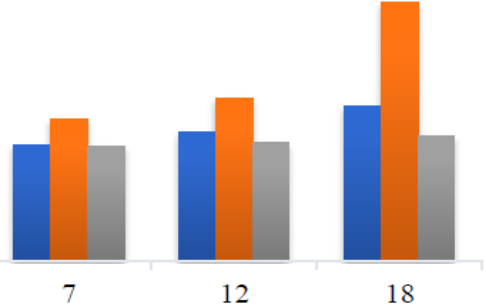

Figure 1. Effect of fermentation Time to Nitrogen Content
The graph in figure 1 indicates that the effect of fermentation time at the nitrogen content in liquid organic fertilizer in each variant of the addition of MOL increased with the longer fermentation time. in line with Sundari et al. (2012) [12], the growth in nitrogen content is thought to be due to the breakdown of natural count number by means of nitrifying microorganism which converts ammonia to nitrate at the cease of the fermentation process. similarly, microorganisms additionally contribute several single-cell proteins obtained throughout the fermentation process, after of entirety of the decomposition process, nitrogen will be released once more as one of the components contained in fertilizers.

The effect of adding MOL of spoiled rice showed an increase in nitrogen content with the maximum condition of adding $50 \mathrm{ml}$ of $\mathrm{MOL}$. Meanwhile, with the addition of $70 \mathrm{ml} \mathrm{MOL}$, the nitrogen content produced was lower than the others. This is due to the fact that the number of microorganisms is not proportional to the amount of available nutrients (the volume of molasses is

$50 \mathrm{ml}$ ), so that the microorganisms experience nutritional deficiencies in the fermentation process or the decomposition process takes place less than perfect. The highest nitrogen content was obtained in the $50 \mathrm{ml}$ MOL addition treatment with a fermentation time of 18 days, which was $0.01296 \%$. While the lowest nitrogen content was obtained by adding $70 \mathrm{ml}$ MOL with a fermentation time of 7 days, which was $0.00578 \%$. 


\subsubsection{Potasium Content}

Potassium in plants is to improve the quality of plant seeds to become fuller and denser, besides that potassium element also improves fruit quality.

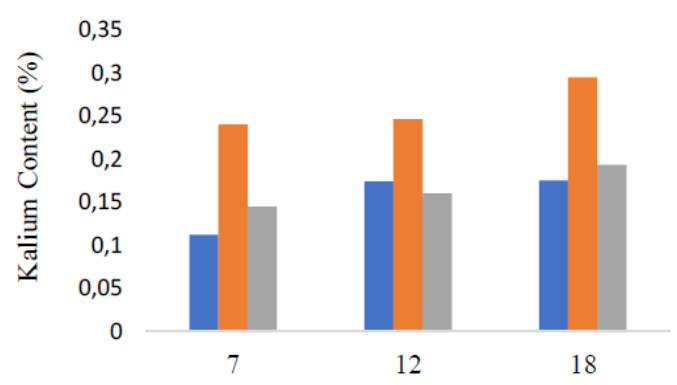

Figure 2. Effect of fermentation Time to Potasium Content

Based on the results of the analysis of the potassium content (as K2O) shown in Figure 2, the K2O content in the resulting liquid organic fertilizer tends to remain the same or experience a slight increase in the length of fermentation time. According to Amanillah (2011)[13], microbes produce potassium compounds and use $\mathrm{K}+$ ions contained in fertilizer raw materials for the benefit of their metabolism so that potassium levels will increase along with the growing number of microbes.

The effect of adding MOL of stale rice to the $\mathrm{K} 2 \mathrm{O}$ content shows the same thing as the nitrogen and phosphorus content, where the more MOL is added, the $\mathrm{K} 2 \mathrm{O}$ content increases to a maximum MOL condition of $50 \mathrm{ml}$. Then at the addition of $70 \mathrm{ml} \mathrm{MOL}$, the resulting $\mathrm{K} 2 \mathrm{O}$ content was lower than the others due to the unbalanced composition of the number of nutrients and microorganisms. The highest $\mathrm{K} 2 \mathrm{O}$ content was found in the $50 \mathrm{ml} \mathrm{MOL}$ addition treatment with a fermentation time of 18 days, which was $0.2947 \%$. The lowest $\mathrm{K} 2 \mathrm{O}$ content produced in the addition of $30 \mathrm{ml}$ MOL treatment with a fermentation time of 7 days was $0.1102 \%$.

\subsubsection{Phosphorus Content}

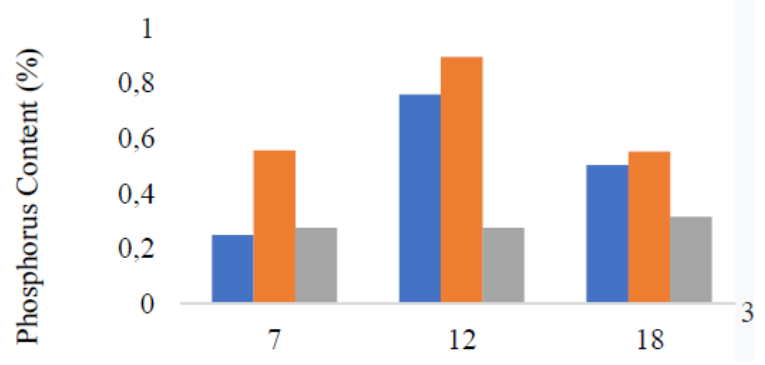

Figure 3. Effect of fermentation Time to Phosphorus Content

The phosphorus content (as P2O5) of liquid organic fertilizer can be seen in figure 3 which indicates that the addition of $30 \mathrm{ml}$ and $50 \mathrm{ml} \mathrm{MOL}$ treatment increased P2O5 content from day 7 to 12 . This is due to the growth factors of microorganisms which initially entered the adaptation phase in the fermentation process, where microorganisms will undergo adjustments and the cell mass can change without changing the number of cells. Then the growth of microorganisms will move to an exponential phase where the microorganisms develop optimally on the number of cells so that the maximum phosphorus content is produced, namely at the time of fermentation for 12 days. However, on the 18th day the P2O5 content in liquid fertilizer decreased, this was due to microorganisms entering a stationary phase, in this phase the number of cell populations remained because the number of cells that grew was equal to the number of cells that died because the available nutrients had decreased [14].

In the treatment with the addition of $70 \mathrm{ml}$ of $\mathrm{MOL}$, the P2O5 content increased slightly with the length of fermentation time. However, the P2O5 content obtained was lower than the addition of other MOL, this was due to the fact that the amount of nutrients (the volume of molasses) was less than the volume of MOL added, so that microorganisms would absorb phosphorus in the substrate for metabolic needs during the fermentation process [14]. The highest P2O5 content was found in the treatment with the addition of $50 \mathrm{ml}$ MOL with a fermentation time of 12 days, which was $0.8928 \%$ and the lowest was in the treatment with the addition of $30 \mathrm{ml} \mathrm{MOL}$ with a fermentation time of 7 days, namely $0,2489 \%$.

\section{CONCLUSION}

Based on the results of the studies that has been executed, it could be concluded that:

1. Production of liquid organic fertilizer of kersen leaves and egg shells with variations in the volume of MOL bioactivator of spoiled rice and fermentation time has an effect on increasing the NPK content.

2. The optimum conditions for the manufacture of liquid organic fertilizer of cherry leaves and egg shells to obtain the best nitrogen, phosphorus and potassium (NPK) content were obtained from the addition of $50 \mathrm{ml} \mathrm{MOL}$ of stale rice. The optimum fermentation time to obtain the best nitrogen and potassium content is 18 days, to obtain the best phosphorus content is 12 days. The NPK content obtained was $0.01296 \% \mathrm{~N}$ and $0.2947 \% \mathrm{~K} 2 \mathrm{O}$ and $0.8928 \%$ P2O5. Liquid organic fertilizer obtained at optimum conditions has a $\mathrm{pH}$ value of 6 , is dark brown in color and has no pungent odor.

3. Based on the Minimum Technical Requirements of PERMENTAN No. 261/KPTS/SR.310/M/4/2019, 
the $\mathrm{pH}$ value of the liquid organic fertilizer of cherry leaves and egg shells produced has met the standard of 4-9. However, the resulting NPK content does not meet the minimum standard of liquid organic fertilizer, which is $2-6 \%$.Liquid Organic Fertilizer Quality Standard.

\section{ACKNOWLEDGMENTS}

The authors would like to thank the Sriwijaya State Polytechnic which has provided PNBP funds for this year 2021 and University Technology Malaysia as a partner for the research. The authors also thank the students who helped in this research.

\section{REFERENCES}

[1] Ramadhani, D. 2010. Pengaruh Pemberian Bakteri Asam Laktat, Bakteri Fotosintetin Anoksigenik dan Bakteri Pelarut Fosfat terhadap Pertumbuhan Tanaman Sawi (Brassica chinesis L var. Tosakan). Fakultas Matematika dan Ilmu Pengetahuan Alam, Universitas Sumatera Utara, Medan.

[2] Lingga, $P$ dan Marsono. 2003. Petunjuk Penggunaan Pupuk. Penebar Swadaya. Jakarta

[3] Mulyo, Agus A., Khoirul Anam ,Lucky Indrati U dan Kindriari Nurma W. 2020. Peningkatan Kualitas Pupuk Cair Daun Kersen (Muntingia C.L) Dengan Penambahan Kotoran Kelinci dan Bioaktivator Em-4. Seminar Nasional Teknik Kimia Soebardjo Brotohardjono XVI. Program Studi Teknik Kimia UPN “Veteran” Jawa Timur.

[4] Iskak, Mohamad. 2014. Pembuatan Pupuk Cair Dari Daun dan Buah Kersen Dengan Proses Ekstraksi Dan Fermentasi. Jurnal Teknik Kimia.

[5] Yuwanta, T. 2010. Telur dan Kualitas Telur.

Gadjah Mada University Press. Yogyakarta

[6] Butcher, D.V.M. Richard, Miles. 2003. Concepts Of Eggshell Quality. Journal. International IFAS Extenion. Institute Of Food And Agricultural Sciences. University of Florida.
[7] Ramaditya, I., Hardiono dan Zulfikar Ali As. 2017. Pengaruh Penambahan Bioaktivator EM-4 (Effective microorganism) dan Mol (Mikroorganisme Lokal) Nasi Basi Terhadap Waktu Terjadinya Kompos, Jurnal Kesehatan Lingkungan. Poltekkes Kemenkes Banjarmasin14 (1). 415- 424.

[8] Julita, S., H. Gultom dan Mardaleni. 2013. Pengaruh Pemberian Mikro Organisme Lokal (MOL) Nasi dan Hormon Tanaman Unggul terhadap Pertumbuhan dan Produksi Tanaman Cabai (Capsicum annum L.). Jurnal Dinamika Pertanian 28 (3): 167-174.

[9] Prahesti R.Y. dan N.U.Dwipayanti. 2011. Pengaruh Penambahan Nasi Basi dan Gula Merah Terhadap Kualitas Kompos dengan Proses Anaerobik. Studi Kasus pada Sampah Domestik Lingkungan Banjar Sari, Kelurahan Ubung, Denpasar Utara

[10] Rajiman. 2020. Pengantar Pemupukan.Yogyakarta: Deepublish Publisher

[11] Damayanti, S.S., Oom Komala dan E. Mulyati Effendi. 2018. Identifikasi Bakteri dari Pupuk Organik Cair Isi Rumen Sapi. Jurnal Ilmiah Ilmu Dasar dan Lingkungan Hidup. 18 (2), 63-71.

[12] Sundari, Elmi. Ellyta Sari dan Riko Rinaldo. 2012. Pembuatan Pupuk Organik Cair Menggunakan Bioakivator Biosca dan EM4. Universitas Bung Hatta Pekan Baru. ISSN. 1907 - 0500.

[13] Amanillah, Zi. 2011. Pengaruh Konsentrasi Em4 pada Fermentasi Urin Sapi Terhadap Konsentrasi N,P, dan K. Skripsi. Fakultas MIPA. Universitas Brawijaya. Malang.

[14] Hidayati,Yulia A, dkk. 2011. Kualitas Pupuk Cair Hasil Pengolahaan Fases Sapi Potong Menggunakan Saccharomyces cereviceae. Universitas Pandjadjaran: Bandung. Jurnal Ilmu Ternak,Vol.11.No.2.,104-107. 